\title{
PLANNING AND DESIGNING AFFORDABLE HOUSING FOR A SUSTAINABLE FUTURE TOWNSHIP IN THE GREATER KUALA LUMPUR REGION, MALAYSIA
}

\author{
AZIM A. AZIZ \& M. HAZIQ ZULKIFLI \\ ATSA Architects, Kuala Lumpur, Malaysia
}

\begin{abstract}
Providing affordable housing for the masses in urban areas in Malaysia plays a significant role in the well-being of the population, contributing to the various social issues including physical and mental health, education, employment and their security as a whole. In Malaysia, the tier percentages of the population have been grouped into three income categories; they are the T20 (top), M40 (middle) and B40 (bottom) groups. Although many public and private housings have been built to cater each income group, they are seemingly unable to address many escalating social and living issues. Currently, the Greater Kuala Lumpur region, as the research area in this study, has a population of 8.3 million. It is projected by the year 2050; the population will reach 10.7 million. Through this paper, a new future township is proposed, whereas many shared facilities and amenities have been incorporated as to avoid the growth of potential social problems and to accord its citizens a conducive living area with great amenities, against the reality of existing conditions. By analysing these issues, a future sustainable township has been formulated based on the three pillar elements, which are live, work, play and learn environment, green areas and convenient connectivity. It is foreseeable that the demands of such township are imperative in the nation building towards achieving Malaysia's goal of attaining highincome economy and a modelled developed nation status soon, graduating from being a developing nation for decades.
\end{abstract}

Keywords: planning, affordable, housing, sustainable, township, Kuala Lumpur, Malaysia.

\section{INTRODUCTION}

Housing has always played a vital role in the nation's economic development and well-being. It is universally regarded as a basic human right, which is to have an adequate standard of living in order to improve living conditions [1]. With the rising global population, housing has often been intertwined with larger social and urban issues. Housing affordability has become commonly discussed issues in particularly urban housing programmes. It is often used as benchmarks to evaluate a city's status and standard of living.

Similarly in Malaysia, especially in the major urban centres, housing affordability has always been the key concern among the masses in recent years. Combined with the rising cost of living, housing affordability continued to be among grave issues, other than the household income, education and employment opportunities, entrepreneurship as well as social safety net [2].

During the independence year of Malaysia (then Malaya) in 1957, the population was only 6.3 million, with 49.8 percent were Malays and Bumiputeras, 37.2 percent Chinese, 11.3 percent Indian and 1.8 percent made of the other races [3]. 60 years later, Malaysia's population rose to 31 million, comprising 68.6 percent Malays and Bumiputeras, 23.4 percent Chinese, 7.0 percent Indians and 1.0 percent of the other races [4]. The population has increased by approximately 25 million people in 60 years, with 32 million population now, a more than threefold from 1957. Around 75 percent of the population now lived in the major urban areas, concentrating in Greater Kuala Lumpur, Penang and Johor [5].

It is anticipated that in years to come the urban population will constitute about 80 percent of the population. Affordable housing has become one of the most important criteria in 
constituting an urban fabric that will propagate growth and other basic human necessities, on top of the jobs, security and a peaceful environment. Furthermore, it is also estimated that the future population will surge up to 41.5 million with a change from the existing demographic where 72.1 percent are Malays and other Bumiputera groups, 20 percent Chinese, 6.4 percent Indian and 1.5 percent of the other races by the year 2040 [6].

In Malaysia, the income of the masses is measured by the government in the three main income groups. Income quintiles are divided into three categories, which are top 20 percent (T20), middle 40 percent (M40), and bottom 40 percent (B40) [7]. The median monthly household incomes now are standing at RM 3,000.00 for B40, RM 6,275.00 for M40 and RM 13,148.00 for T20 [6]. However, to target more accurately the affordability of the housing rate for the purchasers, the categories need to be examined carefully. At present, there are various types of schemes are aiming to provide affordable housing, for instance, housings provided by PR1MA Corporation, National Housing Company Berhad (SPNB), Selangor State Government (Selangorku Homes) and Federal Territory Homes (RUMAWIP) [8].

A concrete measure to address housing affordability should be inclusive, that will look into varying angles and areas. Other than income brackets and economic perspective, it is also vital to incorporate the design of sustainable and affordable housing, as this is very much highlighted in this study. It is also an attempt to find a solution to address the severe issue of affordable housing for the masses that are liveable and conducive to propagate a civil, educated and matured society. In this paper, the Greater Kuala Lumpur region in Malaysia has been chosen as the research area.

\section{RESEARCH METHODOLOGIES}

A qualitative approach has been primarily used in this research. Data and sources on the housings, economic indicators and related design reference were sought through online referencing and several newspapers and journal articles. Secondary data were obtained mostly from reports, articles, proceedings, books, newspapers and journals.

As the most populated region in Malaysia, the Greater Kuala Lumpur region has been selected as the research area of this study. Furthermore, purposely in this research, the research area encompasses the whole area of the state of Selangor, Federal Territories of Kuala Lumpur and Putrajaya with a total land area of 8,223 square kilometres $(2,031,948$ acres) [4]. The future larger expansion of Klang Valley or officially known as Greater Kuala Lumpur is one of the key reasons behind this inclusion.

The boundary area of Greater Kuala Lumpur is currently defined by the ten local authorities in Selangor, Kuala Lumpur and Putrajaya [9]. The ten municipalities are included Ampang Jaya, Kajang, Klang, Kuala Lumpur, Petaling Jaya, Putrajaya, Selayang, Sepang, Shah Alam and Subang Jaya that makes up an area of 2,163 square kilometres or 534,488 acres [10]. Based on the historical, current and projected population, the development of Klang Valley has been propelled exponentially along the Klang River basin and will continue to spread upwards and downwards in the future, which shall include the Selangor (north) and Langat (south) River basin respectively.

This study is aimed to propose a new affordable and sustainable housing model through design and architecture based on the occupant's economic conditions and living requirements. To formulate such design, it is imperative to investigate the population growth and projection for Malaysia and specifically in the Greater Kuala Lumpur region. The obtained data were further analysed and studied with the different income level groups with the existing and projected of affordable housing supply. 


\section{BACKGROUND STUDIES AND FINDINGS}

To date, the population of Greater Kuala Lumpur stood at 7,750,300 people and slated to expand to approximately 10,000,000 people by the year 2020. Taking into account of today's population at 7,750,300 people, based on the figures supplied by the Department of Statistics, Malaysia, [4], there are about 1,830,000 households in Selangor, Kuala Lumpur and Putrajaya. To cater for $10,000,000$ population by the year 2020 , it is anticipated that the number of people will have to increase up to 2,500,000 with at least 2,000,000 people that will need to live in affordable houses in the next three years. However, based on the primary projection data, the population increase of Greater Kuala Lumpur to 10,000,000 people and it seem to be rather ambitious. Based on our analysis, the population would only increase to approximately $8,700,000$ people by the year 2020 and the approximate addition of only 949,700 people by the year 2017 .

To achieve the projected 10,000,000 population in 2020, the Greater Kuala Lumpur has to grow about 563,000 people per year, which is around 7.25 percent growth per year. However, based on a more realistic average annual population growth projection of the Greater Kuala Lumpur, which is about 2.6 percent each year, it is anticipated that by the year 2020, we can only achieve 8,720,900 people living in the Greater Kuala Lumpur region. To obtain the expected 10,000,000 population of Greater Kuala Lumpur, it is anticipated that it can only be achieved by the year 2028. By the year 2050, the population of Greater Kuala Lumpur will stand at $11,000,000$ people and $12,000,000$ people by the year 2100 . The total expected population of Malaysia would be between 40,000,000 to 60,000,000 people at its maximum, depending on the growth model used to project the country's population growth.

Keeping the trend with many other developed nations, Malaysia will face an ageing population soon, as per indicated in the population chart. Based on the data, Malaysia will start experiencing an ageing population issue as early as the year 2040, when the population growth begins to stagnate. The similar figure is also prevalent in the Greater Kuala Lumpur region as the population is capped at 10 million people, not exceeding more than 11 million for the next 60 years.

In another analysis, the decreasing and stagnant population will pose many significant effects economically, other than social and general country well-being. Ideally, the population growth needs to be upkeep at $2.1 \%$ growth rate per year, for a country to be functioned orderly and sustainable [11]. To counter the declining growth, migration is the key to address the population imbalance and continue to spur the economic and development growth.

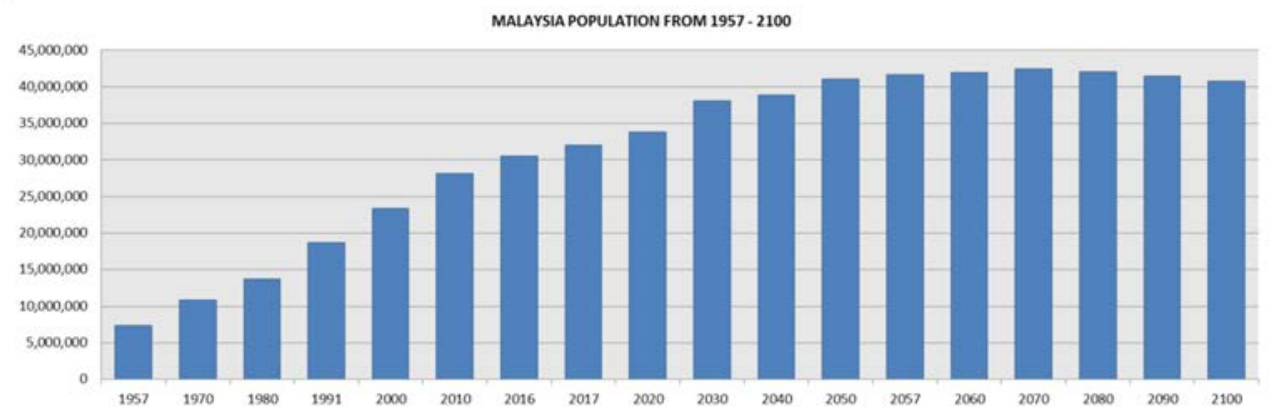

Figure 1: Malaysian population from 1957 to 2100, based on data projection by Department of Statistics, Malaysia and UN Department of Economic and Social Affairs. 
Table 1: Assumption growth rate of the national (Malaysian) population and the Greater Kuala Lumpur population from years 1957 to 2100.

\begin{tabular}{|c|c|c|c|c|c|c|c|c|c|c|c|}
\hline Yea & 957 & 1970 & 1980 & \multicolumn{2}{|c|}{1991} & \multicolumn{2}{|c|}{2000} & \multicolumn{2}{|c|}{2010} & 2017 & 2020 \\
\hline M'si & ,393,000 & $\begin{array}{c}10,860, \\
000\end{array}$ & $\begin{array}{c}13,772, \\
000\end{array}$ & \multicolumn{2}{|c|}{$\begin{array}{c}18,709 \\
000\end{array}$} & \multicolumn{2}{|c|}{$\begin{array}{c}23,420 \\
000\end{array}$} & \multicolumn{2}{|c|}{$\begin{array}{c}28,119 \\
000\end{array}$} & $\begin{array}{c}32,049 \\
700\end{array}$ & $\begin{array}{c}33,782, \\
400\end{array}$ \\
\hline KL & $1,012,929$ & $2,077,430$ & $2,364,067$ & \multicolumn{2}{|c|}{$2,788,113$} & \multicolumn{2}{|c|}{$3,307,419$} & \multicolumn{2}{|c|}{$7,202,672$} & $8,259,000$ & $8,720,900$ \\
\hline & & & 50 & & & & 0 & & 205 & 20 & 2100 \\
\hline M'sia & $\begin{array}{c}38,062, \\
200\end{array}$ & $\begin{array}{c}41,503, \\
100\end{array}$ & $\begin{array}{c}41,100 \\
000\end{array}$ & $\begin{array}{c}41,690 \\
000\end{array}$ & & 5. & $\begin{array}{r}42,4 \\
00\end{array}$ & & $\begin{array}{c}42,059, \\
000\end{array}$ & 7 , & $\begin{array}{c}40,778 \\
000\end{array}$ \\
\hline GK & $\begin{array}{c}9,761 \\
000\end{array}$ & $\begin{array}{c}10,641, \\
000\end{array}$ & $\begin{array}{c}10,715 \\
039\end{array}$ & $\begin{array}{c}10,701, \\
823\end{array}$ & & ,778, & $\begin{array}{r}10,8 \\
32\end{array}$ & & $\begin{array}{c}10,875, \\
202\end{array}$ & $\begin{array}{c}10,907 \\
490\end{array}$ & $\begin{array}{c}10,929 \\
079\end{array}$ \\
\hline
\end{tabular}

\subsection{Affordable housing scene in Malaysia}

Since the post-independence period in 1957, the provision of low-cost and affordable housing has become a priority of the government, especially in the urban areas, where squatter settlements, also known as shanty towns, were prevalent during the early years. Several government agencies were also directly responsible for providing housings for the poor in urban areas through the establishment of the respective state economic development corporations and various urban development agencies, such as the Urban Development Authority (UDA) and local authorities [12].

After the successful eradication of the squatter colonies throughout many urban areas, the problem of proper well-planned affordable housing has become the next challenge. From the last two economic downturns, which were in 1997 and 2008, there seems to be an acute shortage of affordable housing. Price of such houses, (landed or strata) has risen tremendously to the point that many could not afford to buy these houses. Cost of land has also contributed greatly to the construction cost, as well as building materials and labour costs.

Other than the federal and state government agencies, the private sector has also commanding role in providing especially the low-cost housings. An imposed regulation of 30 percent or in some instances up to 50 percent of the total provision for units-built quota for the building of low-cost and affordable housing in every residential development. Ensuring that the targeted group secures these houses, the government has also imposed an open registration system and selection of housing units through a balloting system.

While in some areas, there is a ruling that some affordable units built must equal to the number of high-cost houses, i.e. 50 percent affordable housings with 50 percent of free pricing houses. This approach has been carried out by allowing these units to be built in the high-rise apartment units. In some instances, the high-priced units partly subsidised for the construction of the low-end or affordable units. Moreover, to be fair to all, a balloting system is often carried out to ensure that there was no favouritism when selling these affordable housing units. There is no specific quota or registered purchaser required for other housing categories. 


\subsection{Overview of housing market prices}

Prior to the Eight Malaysian Plan (2001 to 2005), from 1957 up to 1998, only low-cost housings were provided by various federal and state government agencies. Beginning in 2001, a segment of affordable housing has emerged due to the increasing demands from larger urban middle and low-income groups, comprises the Middle 40 (M40) and Bottom 40 (B40).

Over the years, housing prices for the low-cost and affordable segment have been steadily rising and differ from one another, depending on the locations, features and providers. The affordable housing segment has been surfaced in the local property market since the year 2001, with the ceiling price at RM 100,000.00 per unit, as per indicated in Table 2.

In the recent years, various definitions of affordable housing in Malaysia can be found depending on the respective agencies, with the prices ranging from as low as RM 42,000.00 (for the low-cost house) up to RM 400,000.00. Generally, according to the official definition by the Department of National Housing, Ministry of Housing and Local Government, houses with the price tag of RM 300,000.00 and below are considered as affordable housing [13]. However, for some private developers, RM 500,000.00 is considered "affordable", as long as it is listed as RM 1,000,000.00 and below [14].

Table 2: Evolution of low-cost and affordable housing prices in Greater Kuala Lumpur from 1970 to 2016.

\begin{tabular}{|c|c|c|c|c|c|c|}
\hline Years & Before 1970 & $1970-1980$ & 1981-1997 & 1998-2001 & 2001-2015 & 2016 \\
\hline $\begin{array}{l}\text { Low Cost } \\
\text { Housing Price } \\
\text { (RM) }\end{array}$ & $\begin{array}{l}5,000.00- \\
12,000.00\end{array}$ & $\begin{array}{c}12,000.00- \\
18,000.00\end{array}$ & $25,000.00$ & $\begin{array}{c}25,000.00- \\
42,000.00\end{array}$ & $\begin{array}{c}30,000.00- \\
42,000.00\end{array}$ & $\begin{array}{c}30,000.00- \\
42,000.00\end{array}$ \\
\hline $\begin{array}{l}\text { Affordable } \\
\text { Housing Price } \\
\text { (RM) }\end{array}$ & & & & & $\begin{array}{c}100,000.00- \\
400,000.00\end{array}$ & $\begin{array}{c}400,000.00 \\
752,000.00\end{array}$ \\
\hline
\end{tabular}

Table 3: The definitions and features of affordable housing by the selected government agencies in Malaysia.

\begin{tabular}{|c|c|c|c|}
\hline Agencies & Price range & Features & $\begin{array}{c}\text { Income } \\
\text { requirements }\end{array}$ \\
\hline $\begin{array}{l}\text { Ministry of Federal } \\
\text { Territories }\end{array}$ & $\begin{array}{l}\text { RM } 63,000- \\
\text { RM 300.000 }\end{array}$ & $\begin{array}{c}3 \text { rooms, } 2 \text { rooms, } 1 \\
\text { room, studio type }\end{array}$ & $<$ RM 10,000 \\
\hline $\begin{array}{l}\text { Department of National } \\
\text { Housing, Ministry of } \\
\text { Housing and Local } \\
\text { Government }\end{array}$ & $<$ RM 300.000 & $\begin{array}{l}\text { Divided into low } \\
\text { cost, low medium } \\
\text { cost, medium cost }\end{array}$ & $<$ RM 5,000 \\
\hline PR1MA Corporation & $\begin{array}{c}\text { RM } 100,000-\mathrm{RM} \\
400,000\end{array}$ & & $\begin{array}{l}\text { RM 2,500- } \\
\text { RM } 15,000\end{array}$ \\
\hline $\begin{array}{l}\text { National Housing } \\
\text { Company Berhad } \\
\text { (SPNB) }\end{array}$ & $\begin{array}{l}\text { RM 100,000- } \\
\text { RM 300,000 }\end{array}$ & & \\
\hline $\begin{array}{l}\text { Selangor Property and } \\
\text { Housing Board (LPHS) }\end{array}$ & $\begin{array}{l}\text { RM 42,000- } \\
\text { RM 250,000 }\end{array}$ & Type A, B, C, D & $\begin{array}{c}<\text { RM 3,000- } \\
\text { RM 10,000 }\end{array}$ \\
\hline
\end{tabular}


Presently, most of the affordable units are of high-density low- or high-rise apartments of about 650 to 950 square feet or below than 1,000 square feet. They are usually equipped with three bedrooms and two bathrooms.

The interpretation of affordable housing, in the global standard, can be attributed to the price-to-income ratio, more commonly known as the "median-multiple". It was developed in 1988 by the United Nations Centre for Human Settlement (UNCHS) and the World Bank under the Housing Indicators Programme [15]. The ratio concept had also been applied in the UN Habitat Housing Indicators Programme, which focused on monitoring the provision and quality of dwellings.

The median multiple of price-to-income ratio refers to the "affordable" price of a house shall stand at the three times of median gross annual income for any households. This is further pursued by UNCHS and the World Bank utilising international data and adapted in the Annual Demographia International Housing Surveys found that the "global norm" for affordability was three times, meaning that if the median price for the whole of a housing market was three times the median gross annual household income, this signals a wellfunctioning housing market.

Back in the year 2014, the common property market prices were found unaffordable to many middle class working families, especially in the Greater Kuala Lumpur region. The mismatch between household income and housing market prices had resulted in the introduction of affirmative actions by the government agencies through various affordable housing programmes. This situation is far-fetched from the official estimates that more than $80 \%$ of the population will need to require affordable housing, especially for the B40 and M40 income group households.

Table 4: The median multiple detailed rating categories by Demographia (2015).

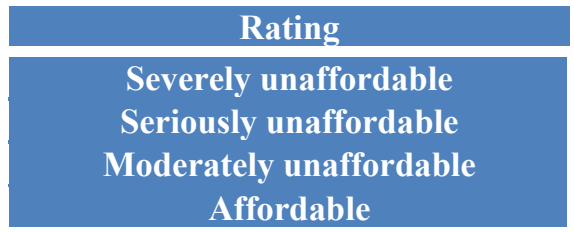

\begin{tabular}{|c|}
\hline Median multiple \\
\hline 5.1 And over \\
\hline $4.1-5.0$ \\
\hline $4.1-5.0$ \\
\hline 3.0 And under \\
\hline
\end{tabular}

Table 5: Household income data obtained from the Department of Statistics, Malaysia, based on the 2014 survey matched with median multiple ratio in Greater Kuala Lumpur.

\begin{tabular}{|l|c|c|c|c|c|c|}
\hline Areas & $\begin{array}{c}\text { Monthly } \\
\text { median } \\
\text { income } \\
\text { (RM) }\end{array}$ & $\begin{array}{c}\text { Annual } \\
\text { median } \\
\text { income } \\
\text { (RM) }\end{array}$ & $\begin{array}{c}\text { Market } \\
\text { median } \\
\text { price } \\
\text { (RM) }\end{array}$ & $\begin{array}{c}\text { Median } \\
\text { all-house } \\
\text { price } \\
\text { (RM) }\end{array}$ & $\begin{array}{c}\text { Median } \\
\text { multiple } \\
\text { afford- } \\
\text { ability }\end{array}$ & $\begin{array}{c}\text { Affordability } \\
\text { level }\end{array}$ \\
\hline $\begin{array}{l}\text { National } \\
\text { (Malaysia) }\end{array}$ & 4,585 & 55,020 & 165,060 & 242,000 & 4.4 & $\begin{array}{l}4.1 \text { to } 5.0 \\
\text { Seriously } \\
\text { unaffordable }\end{array}$ \\
\hline $\begin{array}{l}\text { Kuala } \\
\text { Lumpur }\end{array}$ & 7,620 & 91,440 & 274,320 & 490,000 & 5.4 & $\begin{array}{c}5.1 \text { and over } \\
\text { Severely } \\
\text { unaffordable }\end{array}$ \\
\hline Selangor & 6,214 & 74,568 & 223,704 & 300,000 & 4.0 & $\begin{array}{c}3.1 \text { to } 4.0 \\
\text { Moderately } \\
\text { unaffordable }\end{array}$ \\
\hline
\end{tabular}


In the recent 2018 Malaysian general election, issues related to affordable housing were often downplayed by the political candidates on both sides, citing the highly critical of this issue to their electorates. The affordable housing issue is predicted to be a highly contentious subject for now and near years to come.

\section{DISCUSSION OF FINDINGS}

The region of Greater Kuala Lumpur, located in the centre of Peninsular Malaysia or West Malaysia, currently hosts about 8 million population. With the land area of around 8,223 square kilometres $(2,031,948$ acres $)$, the region is foreseen can accommodate a maximum up to 18 million people, though this may not be the case based on the current and projected population.

Despite the generally massive and flat land area of the Greater Kuala Lumpur region, as well as new property launched every year, the affordable homes remain to be inadequate, especially for the B40 and M40 income group households. According to Ling et al. [16], three major factors would likely attribute to the unaffordable housing scenario, including the mismatch in supply and demand, unaffordable new launches and imbalance between house prices and household incomes.

The mismatch of house supply concurred with the data supplied by the Valuation and Property Services Department [17], as the existing supply of new house in is 1,811,304, sharply lower than the number of 2,064,750 units needed for the population of Greater Kuala Lumpur.

The new property launches also skewed towards unaffordable range, with only $24 \%$ of the new launch price of RM 250,000 and below, in contrast with $35 \%$ of the population that can afford houses priced up to RM 250,000 [16]. In another way, it has shown the new property launches distorted into the high-end segment market.

Another key factor would be the imbalance of growth between house prices and household income. The house prices grew by a big leap of $9.8 \%$ from the year 2007 to 2016, higher than that of household income, that stands at $8.3 \%$ only [16].

\section{OUTCOMES}

Based on the obtained data and information on the current affordable housing scenario in Greater Kuala Lumpur, it is time for concerted efforts from multi-agencies and parties in tackling the issue holistically. In this study, we have outlined our proposal and recommendations in the following sub-sections.

\subsection{Authority regulations and legislations}

Government intervention is vital for any successful affordable housing programmes. In Malaysia, various agencies were set up through the federal government, state government and local authorities. At the federal government level, the Ministry of Housing and Local Government has the power to enact the National Housing Policy. On land matters, it is under the jurisdiction of state government while local authority oversees the zoning and building by-laws [18].

The legislation can be implemented in terms of the affordable housing quota requirement for each new development. For instance, in Selangor state, in some areas, it is now a requirement that the number of units built must be at least 50 percent of them to be affordable and the remaining 50 percent can be built to cater for the higher cost housings [19].

Other regulations can also be implemented in terms of the density requirement, provision of public amenities, as well as in terms of economic and financial sector, that will be 
discussed further in the following sub-chapters. A possible regulation and legislation related to rental market can also be introduced by the local authority to boost the rental accommodation market, especially for low-income households.

While in terms of the procurement and compliance of construction works, the local authority may accelerate and improve the approval time for any planning or building plan submissions. The local authority may also propose lower application fees and provide a density bonus for any affordable housing projects [16].

The built quality and cost also need to be controlled by hiring good and reputable contractors to avoid any excessive and unwanted construction costs. This is staunchly achievable with constant monitoring and supervision by the appointed consultants in every single aspect from the building, engineering, landscaping, costing and other technical specialities.

Recently, the Ministry of Housing and Local Government has mulled to streamline all government affordable housing projects under one agency, namely the National Affordable Housing Council. Should this proposal is actualised, it would effectively synchronise all applications and processes related to public affordable housing programmes, with currently 20 various agencies at federal and state level [18]. Alternatively, inter-agencies cooperation and coordination must be established and improve for a better deliverance of affordable housing programmes nationwide.

\subsection{Economic and financial measures}

Building affordable homes shall not be a costly affair, despite the rising and inflate costs of construction, which include material, labour and land costs. In any development, the land cost and construction works constitute a larger portion at 35\% and 30\% respectively, as per the chart shown in Fig. 2.

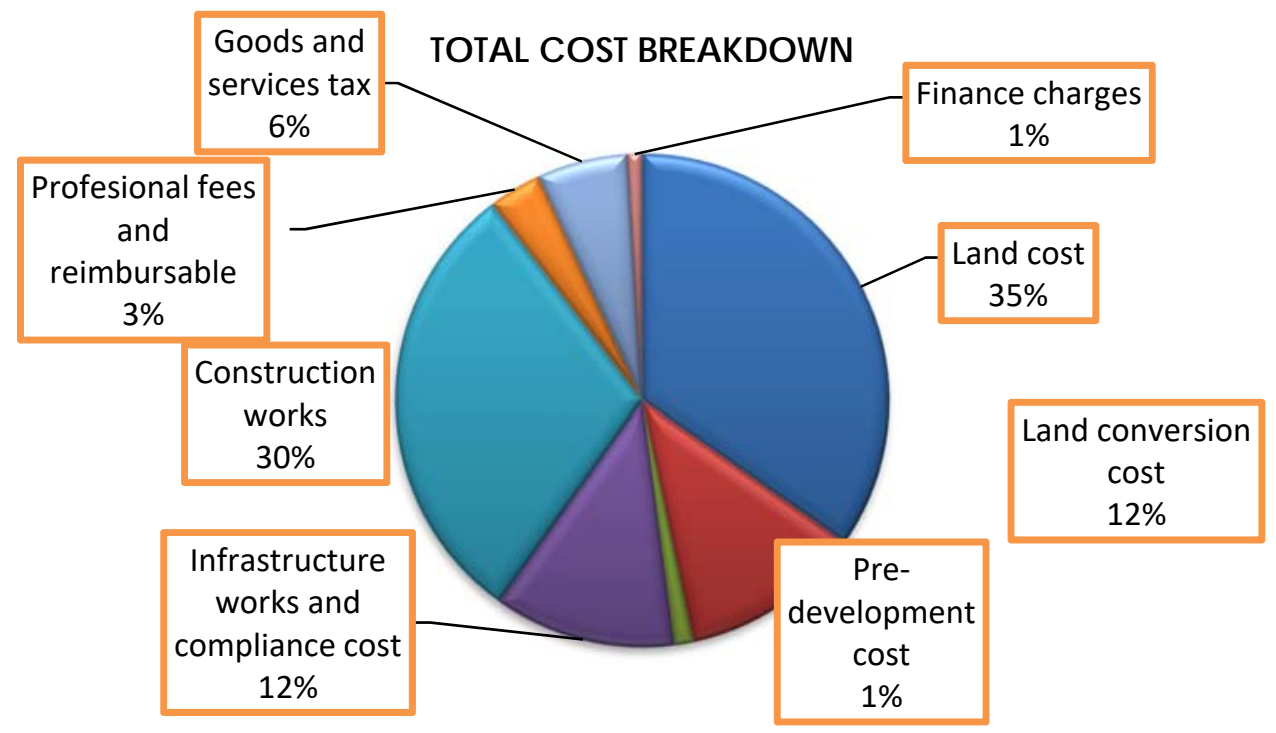

Figure 2: Tabulation of construction cost breakdown. 
The abundance and over-reliance of cheap foreign labours shall be re-examined by adopting more advanced construction methods, such as the Industrialised Building System (IBS) and possibly robotic machinery. A special incentive and tax exemption can also be offered, which will lower the overall construction cost, as well as the labour cost.

The establishment of a single entity such as the National Affordable Housing Council by the government can effectively further reduce the construction cost. This will enhance the purchasing power to employ smarter procurement methods and ensure a steady stream of the project, with additional cost savings from bulk buying of construction materials [16].

In terms of banking and financial facilities, the banking institutions can introduce tailored financial schemes, such as the first time house buyer schemes or rent-to-own home ownership plans. The duration of the loan can also be extended up to 30 years and more. Lower interest rates can be introduced with subsidised fees for low cost and affordable housing loan schemes.

Besides that, the imposition of Real Property Gains Tax (RPGT) restrictions from time to time can also be made to curtail speculation of prices. Similar restrictions can be applied to the second time house buyers, but more supports can be done for young and low to middleincome house buyers or assistance in providing house deposit, such as MyDeposit scheme by the Ministry of Housing and Local Government.

Last but not least, in the short run, at government end, higher yearly allocation can be pumped more into the building of affordable housing projects. At longer run, there must be a measure to alleviate the disposable household income, especially for urban dwellers in the Greater Kuala Lumpur region.

\subsection{Design and planning strategy}

Good architecture and design are imperative in creating a harmonious and pleasant built environment for our lives and well-being. In our design and planning proposal, we have outlined several suggestions from the top to bottom approach, at the macro level to the micro level in the layout planning of township and unit design of affordable housing.

At the current existing land use, the affordable housing can be planned and built on the public land and idle-land, as this has been in practice for some local authority [20]. TransitOriented development can also be planned, especially on the land banks of Malayan Railways Berhad (KTM) or Prasarana Berhad (Light Rail and Mass Rapid Transit operator), particularly near the railroads and train stations. In other cities, such as New York City in the United States, an unconventional infrastructure decking is a pragmatic approach, where affordable housings are built on top existing infrastructures such as rail lines [16].

At macro planning level, if the land area of Greater Kuala Lumpur is mapped and demarcated conceptually by $10 \times 10$ kilometres land mapping, a total of 74 land areas can be developed, with a total of 1,827,800 acres of land. With a proposed density of 30 per acre, this region can be easily fitted up to 54,834,000 people, as shown in Fig. 3.

A 100 square kilometres township area is envisaged to be an integrated live, work and play area, plus a place to learn and enjoy too. A future sustainable township is a culmination area where all sorts of public amenities and facilities, such as neighbourhood market, restaurants, retail shops and offices can be found and interconnected within easy walking reach. This township ought to be a self-sustaining urban village, where it is designated to be a car-less zone with a systematic mode of public transportation.

The township will be divided into four major zones, which are the commercial, residential, institutional and recreational areas, supplemented by a pocket of green parks and plazas 
within. To further boost its connectivity, the angular grid form of planning will be implemented, eases movement from one end to another.



Figures and legend:

- $\quad 74$ x 100 sq.km. $=7,400$ sq.km.

247 acres $\times 7,400=$ $1,827,800 \times 30$ people / acres $=$ up to $54,834,000$ people at 30 density per acre $(* 1 \mathrm{~km}=247$ acres $)$

- 2017 population of Greater KL

$=8,259,000 / 32,049,700$ or $26 \%$ of total Malaysian population

Figure 3: Land area demarcation of Greater Kuala Lumpur region.
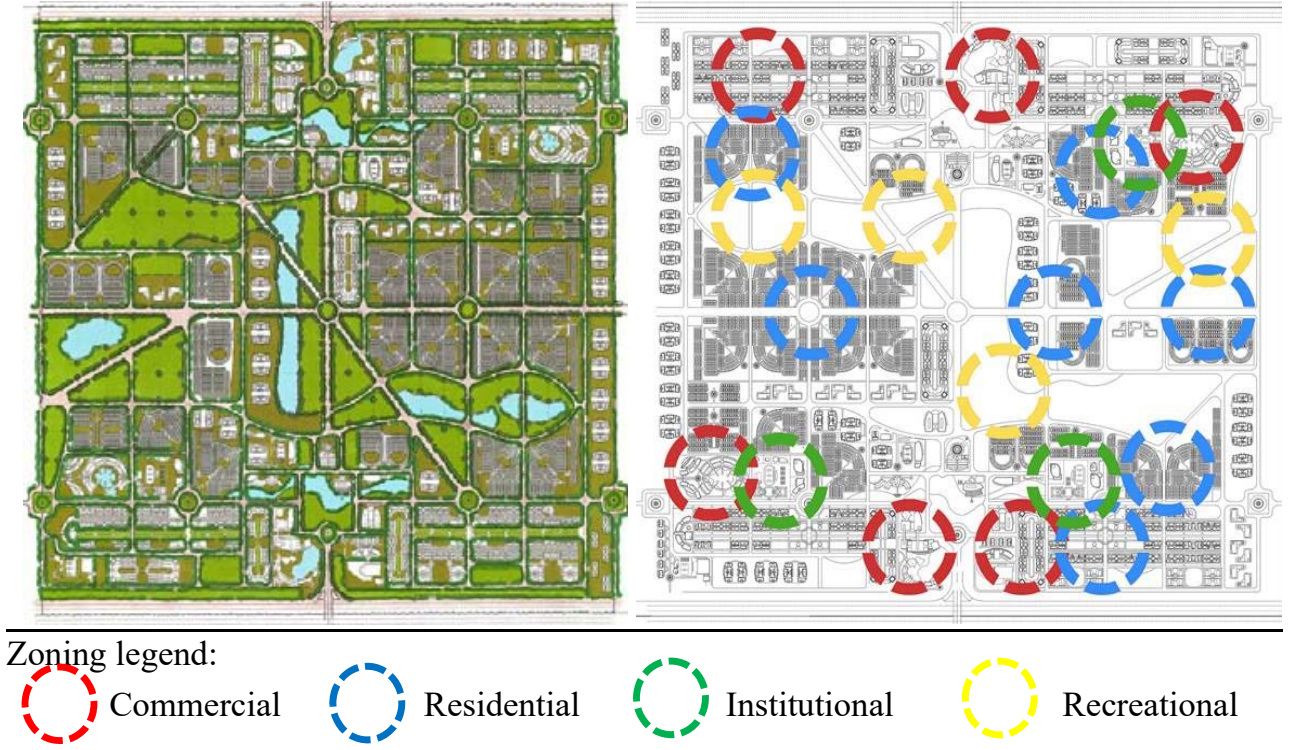

Recreational

Figure 4: Design proposal of planning and zonings for a future sustainable township. 
At the micro level, the layout design of each affordable house unit can be reviewed to match with the current and updated lifestyle. The typical affordable specifications comprise a built-up area of 850 to 1,000 square feet with three bedrooms, two bathrooms and other common spaces. This can be enforced with a revised density of units. Proposed density for affordable housing can be up to 110 units per acre or more for standalone development in Selangor. While in Kuala Lumpur, the building unit density could be much higher and up to 250 units in its density per acre. This depends on the area and the demand for such development at the centre of the city. Alternatively, the land requirements for each development can be minimised too by reducing parking facility requirement. The omission of parking space will inevitably reduce the land required for it, thus paving for more affordable housing units in each development [21].

Hence, the increased density and reduced parking requirement will encourage more people to live in accessible locations, where transportation costs can be minimised. This is where and how an effective public transportation can play its role in increasing connectivity and encourage urban sprawl. A good and interconnected public transportation system consists of trains, rail transits, trams and buses are indispensable in a future sustainable township of the Greater Kuala Lumpur region.

The provision of public facilities such as schools, playgrounds and multi-purpose halls, must be built together with other amenities such as open areas and recreational areas to promote racial and social integration, especially among the different income groups. This will also, in turn, save land required and costs in providing public facilities for the masses.

Another aspect that should be taking into consideration is the maintenance and building lifespan. One of the biggest challenges is to maintain such housings so that it will not turn into disrepair after its completion. It must grow its ecosystem to allow for sustainable living in the long run. One must also think about the lifestyle or lifespan of such housings as they may need to be replaced or renovated/refurbished every 20 to 30 years after its completion.

\section{CONCLUSIONS}

The affordable housing scenario is not unique to the Greater Kuala Lumpur region only, but in fact is an epidemic issue in many major cities around the world. However, as the most developed region of Malaysia, affordable housing will continue to be a contentious issue in many years to come. With the population is projected to be $8,720,900$ people by the year 2020 , the supply of affordable housing is on the rise to meet the increasing demand and growing population.

Nevertheless, in order to improve and solve issues pertaining to the affordable housing, combined efforts must be made to tackle the deep-rooted issues that prevent the adequate supply of reasonably priced housings, which is the affordability of owning a house and prices of the house itself. Several aspects of regulations and legislation can look into empowering the lower cost of building and owning an affordable house. Similar efforts can be pushed from the financial and banking sector in creating a more viable property market through economic measures. While in terms of design and planning, architects, planners and other professionals can start to emulate such unconventional and innovative ideas in creating not only affordable but also sustainable housings and townships.

In a long-term goal, it will not merely providing adequate and affordable housing units, but also into creating a conducive living environment, with a provision of maintenance and upgrading or refurbishment in the future, in tandem with the improved economic standing of the households.

Building a liveable township and city at the international standard is a great opportunity for the Greater Kuala Lumpur region and also Malaysia. Building purely for affordable 
housing in cities and townships may not enough in the short terms, but building future communities that will enhance the liveability of its people is the way that the policymakers must pursue. This, in turn, will make the Greater Kuala Lumpur region as one of the best places to live in the world with the improved quality of life for its population.

The Greater Kuala Lumpur region is in a great position to build townships that can apply new ideas, technologies and sustainable living. Broad ideas include types of dwellings, mixed development and connectivity living to be thought through in great detail and provide the future communities with a place to live, work, learn and play. The goal is to become one of the best places to live with an abundance of opportunities.

\section{REFERENCES}

[1] Office of the United Nations High Commissioner for Human Rights The Right to Adequate Housing, United Nations: Geneva, 2014.

[2] Economic Planning Unit, Eleventh Malaysia Plan 2016-2020, Economic Planning Unit: Putrajaya, 2015.

[3] Chander, R., 1974 World Population Year: The Population of Malaysia, Committee for International Cooperation in National Research in Demography: Paris, 1975.

[4] Current Population Estimates, Malaysia, 2014-2016, Department of Statistics: Putrajaya, 2016.

[5] Urban population (\% of total); United Nations Population Division, The World Bank Data. Online. data.worldbank.org/indicator/SP.URB.TOTL.IN.ZS?locations=MY. Accessed on: 28 Nov. 2016.

[6] Malaysia @ a Glance; Department of Statistics, Malaysia, Online. www.dosm.gov.my/v1/index.php?r=column/cone\&menu_id=ZmVrN2FoYnBvZE05 T1AzK0RLcEtiZz09. Accessed on: 11 Jun. 2018.

[7] Mohd, S., Senadjki, A., Che Hamat, A.F. \& Bahari, Z., Income inequality in the Northern States of Malaysia: An analysis of income quintile. Proceedingss of International Conference on Development and Socio Spatial Inequalities 2015, pp. 105-112, 2015.

[8] Abdullah, Y.A., Jamaluddin, N.B., Ling, H.L., Omar, D. \& Abdul R., Adaptive SocioEcon-Enviro Responsive Affordable Housing Model. Presented at The 4th International Building Control Conference 2016, Kuala Lumpur, Malaysia, 2016.

[9] PwC, Greater Kuala Lumpur: Bridge between Asia and the World, PricewaterhouseCoopers Taxation Services: Kuala Lumpur, 2017.

[10] Demographia, Demographia World Urban Areas, Wendell Cox Consultancy: Belleville, 2018.

[11] UN Population Division, Total Fertility Rate, United Nations Department of Economic and Social Affairs: New York, 2008.

[12] Shuid, S., Low medium cost housing in Malaysia: Issues and challenges. Research Gate, pp. 1-13, 2016.

[13] Abu Bakar, D. \& Jusoh, H., Community wellbeing in the scope of sustainable affordable housing. Malaysian Journal of Society and Space, pp. 97-114, 2017.

[14] Affordable housing and the emergence of a new norm, The Edge Property. Online. www.theedgeproperty.com.my/tags/affordable-housing. Accessed on: 29 Nov. 2016.

[15] Cox, W. \& Pavletich, H., 14th Annual Demographia International Housing Affordability Survey: 2018, Demographia: Belleville, 2017.

[16] Ling, C.S., Almeida, S.J. \& Wei, H.S., Affordable housing: Challenges and the way forward. Economic and Financial Developments in the Malaysian Economy in the Fourth Quarter of 2017, Central Bank of Malaysia: Kuala Lumpur, pp. 19-26, 2018. 
[17] Valuation and Property Services Department, Property Stock Report, Valuation and Property Services Department, Putrajaya, 2016.

[18] Kenas, T., Suwardi, A., Ling, N.P. \& Hassan, H., Ownership On The Horizon, Star Property.my, The Star: Petaling Jaya, 2018.

[19] Hassan, M., 'Selangorku Homes'-Policy and Planning Methods in Affordable Housing of Selangor State. Presented at Seminar on Selangorku Homes and Strata Management Act, Shah Alam, Malaysia, 2015.

[20] A Blueprint for Addressing the Global Affordable Housing Challenge, McKinsey Global Institute: New York City, 2014.

[21] Chen L.L.E., Minimum parking and housing affordability. Property Take, The Sun: Petaling Jaya, 2018. 